\title{
Herbicides for Container-grown Rain Forest Species
}

\author{
K.V. Sharman ${ }^{1}$ \\ Queensland Department of Primary Industries, Redlands Research Station, \\ Cleveland, Queensland 4163, Australia
}

Additional index words. Dysoxylum rufum, Syzgium fibrosum, Alphitonia excelsa, Macaranga tanarius, Acmena hemilampra, Metrosideros queenslandica, Arytera lautereriana, Polyscias elegans, Ficus racemosa, Cardwellia sublimis, oxadiazon, simazine, oxyfluorfen, oryzalin, dichlobenil, Proteaceae

\begin{abstract}
Four granular formulations of preemergence herbicides-oxadiazon, oxadiazon in combination with simazine, dichlobenil, and oxyfluorfen + oryzalin-were evaluated for weed control and phytotoxic effects on 10 species of container-grown Australian rain forest plants. Herbicides were applied at half and at one and two times the manufacturer's recommended rate. Oxyfluorfen + oryzalin, oxadiazon, and oxadiazon + simazine controlled all weed species at half the recommended rates $\left(1.0+0.5,2.0\right.$, and $2.0+0.5 \mathrm{~kg}^{-h^{-1}}{ }^{-1}$ respectively) with no phytotoxic effects after 10 weeks to nine of the 10 rain forest species tested: broad-leafed lilly-pilly [Acmena hemilampra (F. Muell. ex Bailey) Merr. and Perry], red ash [Alphitonia excelsa (Cunn. ex Fenzl) Reisseck ex Benth.], rusty bean [Dysoxylum rufum (A. Rich.) Benth.], macaranga [Macaranga tanarius (L.) Muell. Arg.], fibrous satinash [Syzygium fibrosum (Bailey) T. Hartley and Perry], Queensland golden myrtle [Metrosideros queenslandica L.S. Smith], cluster fig [Ficus racemosa L.], corduroy tamarind [Arytera lautereriana (Bailey) Radlk.], and celerywood [Polyscias elegans (F. Muell and C. Moore) Harms]. Dichlobenil depressed plant growth of red ash and failed to control bittercress (Cardamine hirsuta L.) and green amaranth (Amaranthus viridus L.), even at twice the recommended rate $\left(4.0 \mathrm{~kg}^{-h^{-1}}\right)$. All herbicides applied at half the recommended rates produced minor to moderate plant injury within 5 weeks of the first application to corduroy tamarind and northern silky oak [Cardwellia sublimis F. Muell.]. A second application 10 weeks after the first caused no significant plant injury to corduroy tamarind but resulted in severe plant injury to northern silky oak. This finding validates the previously reported sensitivity of Proteaceous spp. to preemergence herbicides. Chemical names used: (2-tert-butyl-4-(2,4-dichloro-5-isopropoxyphenyl)- $\Delta^{2}-1,3,4$ oxadiazoline-5one) (oxadiazon); (2-chloro-4,6-bisethylamino-1,3,5-triazine) (simazine); 2,6dichlorobenzonitrile (dichlobenil); 2-chloro-1-(3-ethoxy-4-nitrophenoxy)-4-(trifluoromethyl)benzene (oxyfluorfen); and 3,5-dinitro- $N^{4}, N^{4}$-dipropylsulfanilamide (oryzalin).
\end{abstract}

Weed control is a major problem in the production of container-grown plants because no phytotoxic postemergence herbicides are available for general use on such crops (Weller et al., 1984) and hand weeding is time consuming and expensive (Currey et al., 1977). Longterm container crops (trees and shrubs) that are grown outdoors are particularly problematic. Some common problem weeds such as creeping oxalis (Oxalis corniculata L.) and bittercress have short life cycles and can flower and reseed in 8 weeks (Lamont, 1984). If not controlled, these weeds can completely occupy containers, particularly in subtropical

Received for publication 10 Oct. 1991. Accepted for publication 31 July 1992. I thank J. Giles for statistical analyses, K. Bodman for advice during the project, L. Mochan for technical support, RhõnePoulenc Pty. and Nufarm for providing chemicals and plants, and J. Gage for comments during the preparation of this manuscript. Reference to trade products is for purposes of publication and does not imply approval or recommendation of the product to the exclusion of others that may be suitable. The cost of publishing this paper was defrayed in part by the payment of page charges. Under postal regulations, this paper therefore must be hereby marked advertisement solely to indicate this fact. areas where climatic conditions are conducive to rapid growth during the year. Long-term production may also allow other larger broadleaf weeds, such as green amaranth and sow thistle (Sonchus oleraceus L.), to establish.

Granular preemergence herbicides are effective against many weeds in containers; however, they cannot be used safely on all container nursery crops (Weller et al., 1984). Oryzalin or oxyfluorfen granules applied at 9 $\mathrm{kg} \cdot \mathrm{ha}^{-1}$ inhibited growth and reduced marketability of Ilex spp. (Singh et al., 1984). Plant injury was less at $2.2 \mathrm{~kg} \cdot \mathrm{ha}^{-1}$ of either herbicide, but Pennsylvania bittercress (Cardamine pensylvanica Muhl.) and yellow wood sorrel (Oxalis dellenii Jacq.) were not controlled. Rhododendron obtusum (Lindl.) Planch. 'Coral Bells' was susceptible to injury when oxyfluorfen granules were applied at the label rate of $2.2 \mathrm{~kg} \cdot \mathrm{ha}^{-1}$, whereas $R$. obtusum Planch 'Hino Crimson' was tolerant to $9.0 \mathrm{~kg} \cdot \mathrm{ha}^{-1}$ (Singh et al., 1981). Rhododendron and Azalea cultivars differed in their sensitivity to dichlobenil granules (Ahrens, 1966). In another study, oxyfluorfen granules combined with oryzalin damaged newly emerging leaves of several container-grown palm species when applied at recommended rates $(4.0+1.0$ $\left.\mathrm{kg} \cdot \mathrm{ha}^{-1}\right)$ (Donselman and Broschat, 1986). Oxadiazon granules are considered safe for use on a range of ornamental species (Lamont et al., 1985; Neel, 1977). Lamont et al. (1985) and Lamont and Spohr (1988) reported that 36 of the 37 Australian native and exotic species evaluated exhibited no phytotoxic effects or reduced shoot dry weight when oxadiazon was applied at $8 \mathrm{~kg} \cdot \mathrm{ha}^{-1}$ (four times the recommended rate). Unacceptable plant injury has been recorded on Ilex spp. from oxadiazon applications at $4.5 \mathrm{~kg} \cdot \mathrm{ha}^{-\mathrm{P}}$ (Singh et al., 1984).

Some Australian rain forest species are becoming popular in the nursery trade where their growth habit, attractive foliage, and colorful flowers and fruit make them salable items (Jones, 1986). In subtropical Australia, these ornamental trees and shrubs are produced outdoors as long-term container crops destined for the landscaping market or reforestation programs. Phytotoxic effects of preemergence herbicides on these species are unknown.

This study evaluated the phytotoxicity of granular preemergence herbicides to rain forest species grown in containers, and assessed their efficacy on weeds prevalent in subtropical nurseries. Granular formulations of oxadiazon, oxadiazon + simazine, dichlobenil, and oxyfluorfen + oryzalin were applied at half and at one and two times the manufacturer's recommended rate: oxadiazon, 2.0, 4.0, and $8.0 \mathrm{~kg} \cdot \mathrm{ha}^{-1}$; oxadiazon + simazine, $2.0+0.5$, $4.0+1.0$, and $8.0+2.0 \mathrm{~kg} \cdot \mathrm{ha}^{-1}$; dichlobenil, $1.0,2.0$, and $4.0 \mathrm{~kg} \cdot \mathrm{ha}^{-1}$; and oxyfluorfen + oryzalin, $1.1+0.5,2.2+1.0$, and $4.4+2.0$ $\mathrm{kg} \cdot \mathrm{ha}^{-1}$. Controls, which received no herbicide, were included for comparison.

The experimental work was conducted at the Redlands Research Station, Cleveland, Australia, a subtropical location (lat. $27^{\circ} 35^{\prime}$ 'S, long. $\left.153^{\circ} 16^{\prime} \mathrm{E}\right)$. Plants were grown in a medium consisting of $50 \%$ composted hardwood sawdust, $25 \%$ composted softwood shavings, $15 \%$ pinebark fines, and $10 \%$ medium (1-mmdiameter grains) washed sand at $\mathrm{pH} 5.8$. Micronutrients (Micromax; Sierra Chemical, Milpitas, Calif.), ferrous sulfate, and isobutylidene diurea were each added at a rate of $0.5 \mathrm{~kg} \cdot \mathrm{m}^{-3}$. Nutricote Black slow-release fertilizer (16N-4.4P-8.3K, 8- to 9-month formulation) (Chisso Asohi Fertilizer Co., Tokyo) was incorporated at $7.5 \mathrm{~kg} \cdot \mathrm{m}^{-3}$ before potting all species except $C$. sublimis (Proteaceae), which received Nutricote Purple (20N-0P-10.8K, 3- to 6-month formulation) because $\mathrm{P}$ toxicity has been reported for some Proteaceae spp. grown in soilless media (Nichols and Beardsell, 1981). Uniform tubestock of 10 rain forest species (Table 1) were planted in 2-liter containers on 11 Aug. 1990. Herbicide treatments were applied 4 weeks after planting and again 10 weeks later. Herbicides at treatment rates were weighed individually for each container; mixed with $20 \mathrm{ml}$ dry, coarse sand; and sprinkled evenly over the soil surface. Containers were placed in full sun and irrigated daily with $500 \mathrm{ml}$ water, except during wet weather. The containers were kept weed free, and plants were observed for symptoms of phytotoxicity 5 weeks after each herbicide application. Phytotoxicity was recorded 
Table 1. Rain forest species evaluated for tolerance to preemergence herbicides.

\begin{tabular}{lcc}
\hline \hline Species & Family & Common name \\
\hline Acmena hemilampra & Myrtaceae & Broad-leafed lilly-pilly \\
Alphitonia excelsa & Rhamnaceae & Rcd ash \\
Arytera lautereriana & Sapindaceae & Corduroy tamarind \\
Cardwellia sublimis & Proteaceae & Northern silky oak \\
Dysoxylum rufum & Meliaceae & Rusty bean \\
Ficus racemosa & Moraceae & Cluster fig \\
Macaranga tanarius & Euphorbiaceae & Macaranga \\
Metrosideros queenslandica & Myrtaceae & Queensland golden myrtle \\
Polyscias elegans & Araliaceae & Celerywood \\
Svzygium fibrosum & Myrtaceae & Fibrous satinash \\
\hline
\end{tabular}

on a scale of $1=$ no plant injury (as in control), $2=$ minor injury, $3=$ moderate injury, $4=$ severe injury, and $5=$ plant died due to herbicide injury. Plant height (in millimeters) was recorded before each treatment (weeks 0 and 10) and 15 weeks later, when shoot dry weight (in grams) was also recorded. Each species represented a separate experiment-a randomized block with three replications using singleplant plots. Analysis of variance of plant height, shoot dry weight, and phytotoxicity data was performed for each experiment.

Treatment efficacy was evaluated for seven weed species in one of two trials: green amaranth, thickhead, bunchy sedge, caustic weed, asthma plant, creeping oxalis, and phyllanthus were used in trial 1; bittercress, scarlet pimpernel (Anagallis arvensis L.), Mexican poppy, cobbler'spegs, smooth cat's ear (Hypochaeris glabra L.), sago weed, and sowthistle were used in trial 2. Herbicides were applied to containers, as described above, on 25 Sept. (trial 1) and 30 Oct. (trial 2) 1990. Forty seeds of each weed species were combined with 20 $\mathrm{ml}$ of dry, coarse sand and sprinkled evenly over each container's surface. Containers were placed in full sun and irrigated with $250 \mathrm{ml}$ water twice daily to maintain a moist surface for germination. Each trial was arranged in a randomized complete-block design with three replications of each herbicide treatment plus three nontreated controls. The number of plants of each weed species in each container was recorded 5 weeks after sowing. Weed counts were transformed by adding 0.5 and taking the square root. Analysis of variance was conducted for each weed species except scarlet pimpernel and smooth cat's ear, which failed to germinate in control pots. Weed control was considered effective if the retransformed mean number of weeds for an herbicide at a given rate was $\leq 25 \%$ of the corresponding retransformed mean of the control. An effective herbicide was one that controlled $\geq 75 \%$ of total weeds (Creager, 1982).

The type of herbicide used significantly influenced weed control. Oxyfluorfen + oryzalin, oxadiazon, and oxadiazon + simazine effectively controlled all weed species at $1.1+0.5,2.0$, and $2.0+0.5 \mathrm{~kg} \cdot \mathrm{ha}^{-1}$, respectively (half the recommended rates) (data not shown); dichlobenil controlled weeds poorly (Table 2). Dichlobenil at $1.0 \mathrm{~kg} \cdot \mathrm{ha}^{-1}$ (half the recommended rate) did not reduce populations of green amaranth, thickhead, asthma plant, and creeping oxalis. There were fewer bunchy sedge, caustic weed, phyllanthus, bittercress, and sowthistle plants at $1.0 \mathrm{~kg} \cdot \mathrm{ha}^{-1}$, but control was not acceptable. Twice the recommended rate of dichlobenil $\left(4.0 \mathrm{~kg} \cdot \mathrm{ha}^{-1}\right)$ was required to control green amaranth and bittercress effectively.

The effect of preemergence herbicides on plant growth and phytotoxicity was species dependent. Broad-leafed lilly-pilly, rusty bean, macaranga, Queensland golden myrtle, and fibrous satinash were not affected by herbicide treatment (data not shown), while plant height and shoot dry weight of red ash decreased with increasing rates of dichlobenil (Table 3).

Phytotoxic symptoms were observed on corduroy tamarind, northern silky oak, cluster fig, and celerywood 5 weeks after herbicide treatment (Table 4). Herbicide-affected plants of susceptible species exhibited lower leaf necrosis. Curling of the new leaves also accompanied lower leaf necrosis in affected plants of celerywood, whereas all leaves on herbicide-affected plants of northern silky oak were necrotic, including the shoot tips. One application of any herbicide at the recommended rate caused minor plant injury to corduroy tamarind, cluster fig, and celerywood, except the application of oxyfluorfen + oryzalin

Table 2. Effect of dichlobenil preemergence herbicide applied at half and one and two times the manufacturer's recommended rate of $2.0 \mathrm{~kg} \mathrm{ha}^{-1}$ on the number of weeds per pot. ${ }^{2}$

\begin{tabular}{|c|c|c|c|c|}
\hline \multirow[b]{3}{*}{ Species } & \multicolumn{4}{|c|}{$\sqrt{\text { No. weeds }+0.5 \text { per pot }}$} \\
\hline & \multicolumn{4}{|c|}{ Amount applied (kg.ha-1) } \\
\hline & 1.0 & 2.0 & 4.0 & 0 \\
\hline & Trial 1 & & & \\
\hline $\begin{array}{l}\text { Amaranthus viridus } \mathrm{L} . \\
\quad \text { (green amaranth) }\end{array}$ & $2.15 \mathrm{~b}$ & $2.38 \mathrm{~b}$ & $1.17 \mathrm{a}$ & $2.29 \mathrm{~b}$ \\
\hline $\begin{array}{l}\text { Crassocephalum crepidioides Benth. } \\
\text { (thickhead) }\end{array}$ & $2.32 \mathrm{~b}$ & $1.00 \mathrm{a}$ & $1.00 \mathrm{a}$ & $2.39 \mathrm{~b}$ \\
\hline $\begin{array}{l}\text { Cyperus polystachyos } \mathrm{L} \text {. } \\
\text { (bunchy sedge) }\end{array}$ & $1.72 \mathrm{a}$ & $1.25 \mathrm{a}$ & $0.88 \mathrm{a}$ & $2.10 \mathrm{~b}$ \\
\hline $\begin{array}{l}\text { Euphorbia drummondii Boiss } \\
\text { (caustic weed) }\end{array}$ & $1.68 \mathrm{a}$ & $1.10 \mathrm{a}$ & $1.29 \mathrm{a}$ & $2.81 \mathrm{~b}$ \\
\hline $\begin{array}{l}\text { Euphorbia hirta } \mathrm{L} \text {. } \\
\text { (asthma plant) }\end{array}$ & $1.17 \mathrm{~b}$ & $0.70 \mathrm{a}$ & $0.70 \mathrm{a}$ & $1.76 \mathrm{~b}$ \\
\hline $\begin{array}{l}\text { Oxalis corniculata } \mathrm{L} \text {. } \\
\text { (creeping oxalis) }\end{array}$ & $1.10 \mathrm{~b}$ & $0.70 \mathrm{a}$ & $0.70 \mathrm{a}$ & $1.10 \mathrm{~b}$ \\
\hline $\begin{array}{l}\text { Phyllanthus tenellus Roxb. } \\
\text { (phyllanthus) }\end{array}$ & $1.56 \mathrm{~b}$ & $0.70 \mathrm{a}$ & $0.70 \mathrm{a}$ & $2.04 \mathrm{c}$ \\
\hline & Trial 2 & & & \\
\hline $\begin{array}{l}\text { Cardamine hirsuta } \mathrm{L} . \\
\text { (bittercress) }\end{array}$ & $1.34 \mathrm{~b}$ & $1.48 \mathrm{~b}$ & $0.88 \mathrm{a}$ & $1.77 \mathrm{c}$ \\
\hline $\begin{array}{l}\text { Argemone mexicana L. } \\
\text { (Mexican poppy) }\end{array}$ & $0.70 \mathrm{a}$ & $0.70 \mathrm{a}$ & $0.87 \mathrm{~b}$ & $1.90 \mathrm{~b}$ \\
\hline $\begin{array}{l}\text { Bidens pilosa } \mathrm{L} \text {. } \\
\quad \text { (cobbler's pegs) } \\
\text { Plantago varia } \mathrm{R} \text {. Br. }\end{array}$ & $1.93 \mathrm{~b}$ & $1.17 \mathrm{a}$ & $1.27 \mathrm{ab}$ & $6.05 \mathrm{c}$ \\
\hline $\begin{array}{l}\text { (sago weed) } \\
\text { Sonchus }\end{array}$ & $0.88 \mathrm{a}$ & $0.88 \mathrm{a}$ & $0.88 \mathrm{a}$ & $1.95 \mathrm{~b}$ \\
\hline $\begin{array}{l}\text { Sonchus oleraceus L. } \\
\text { (sowthistle) }\end{array}$ & $1.34 \mathrm{~b}$ & $1,17 \mathrm{~b}$ & $0.70 \mathrm{a}$ & $2.10 \mathrm{c}$ \\
\hline
\end{tabular}
injury recorded after the first application and and dichlobenil to cluster fig, which remained uninjured (Table 4). No further phytotoxic effects were observed on treated plants of these species after herbicides were applied a second time (10 weeks later). Mean plant height of corduroy tamarind, cluster fig, and celerywood at that time was $58 \% \pm 5 \%, 80 \%$ $\pm 7 \%$, and $41 \% \pm 3 \%$ greater, respectively, than at the first application. Therefore, the phytotoxic effect may have been less after the second application because plants were larger; hence, the dose of herbicide per shoot or root weight was reduced.

Northern silky oak was highly susceptible to preemergence herbicides, with moderate severe injury after the second, even at half the recommended rates. The Proteaceae may be particularly susceptible to preemergence herbicides, since other members of this familyGrevillea, Protea, Leucospermum, and Banksia-are also reported to be sensitive. Lamont and Spohr (1988) reported that containergrown Grevillea hookeriana Meisner and $G$. juniperina $\mathrm{R} . \mathrm{Br} . \times$ G. rosmarinifolia Cunn. 'Pink Lady' exhibited marginal leaf necrosis and had reduced dry weight when oxadiazon + simazine was applied at $4.0+1.0 \mathrm{~kg} \cdot \mathrm{ha}^{-1}$, while $G$. laurifolia Sieber ex Sprengel $\times G$. willisii R.V. Smith and McGillivray 'Royal Mantle' was more sensitive, with plant injury occurring at $2.0+0.5 \mathrm{~kg} \cdot \mathrm{ha}^{-1}$. In another study, plant growth of Protea neriifolia $\mathrm{R}$. Br. 'Pink Mink' was reduced in field plantings after application of oryzalin, alone and with simazine, at 4.5 and $3.5+1.1 \mathrm{~kg} \cdot \mathrm{ha}^{-1}$, respectively (Besemer and Elmore, 1987). Field-grown Banksia and Leucospermum spp. were also damaged by simazine (Nishimoto, 1975). 
Table 3. Effect of preemergence herbicides on red ash shoot dry weight and plant height. ${ }^{z}$

\begin{tabular}{llcc}
\hline \hline & $\begin{array}{c}\text { Amount } \\
\text { applied } \\
\left(\mathrm{kg}^{-1} \mathrm{~h}^{-1}\right)\end{array}$ & $\begin{array}{c}\text { Shoot } \\
\text { dry wt } \\
(\mathrm{g})\end{array}$ & $\begin{array}{c}\text { Plant } \\
\mathrm{ht} \\
(\mathrm{mm})\end{array}$ \\
\hline Oerbicide & 2.0 & $54.8 \mathrm{c}$ & $875 \mathrm{bc}$ \\
& 4.0 & $46.8 \mathrm{bc}$ & $790 \mathrm{ab}$ \\
Oxadiazon & 8.0 & $46.8 \mathrm{bc}$ & $843 \mathrm{a}-\mathrm{c}$ \\
& $2.0+0.5$ & $48.5 \mathrm{bc}$ & $850 \mathrm{a}-\mathrm{c}$ \\
& $4.0+1.0$ & $55.0 \mathrm{c}$ & $817 \mathrm{a}-\mathrm{c}$ \\
Oxyfluorfen + oryzalin & $8.0+2.0$ & $42.0 \mathrm{ab}$ & $865 \mathrm{bc}$ \\
& $1.1+0.5$ & $42.0 \mathrm{ab}$ & $740 \mathrm{a}$ \\
Dichlobenil & $2.2+1.0$ & $48.0 \mathrm{bc}$ & $823 \mathrm{a}-\mathrm{c}$ \\
& $4.4+2.0$ & $48.7 \mathrm{bc}$ & $892 \mathrm{bc}$ \\
& 1.0 & $54.7 \mathrm{~b}$ & $878 \mathrm{bc}$ \\
Nontreated control & 2.0 & $43.8 \mathrm{~b}$ & $827 \mathrm{a}-\mathrm{c}$ \\
& 4.0 & $33.0 \mathrm{a}$ & $737 \mathrm{a}$ \\
& & $54.5 \mathrm{c}$ & $911 \mathrm{c}$ \\
\hline
\end{tabular}

${ }^{2}$ Mean separation within columns by LSD at $P \leq 0.05$.

As with other members of the Proteaceae, northern silky oak has specialized proteoid roots that form in dense clusters near the soil surface and are believed to play a role in selective nutrient uptake (Jeffrey, 1967; Vorster and Jooste, 1986). Proteoid roots may also be more metabolically active than ordinary roots (Smith and Jooste, 1986). To account for the high incidence of plant injury after application of oxidiazon in combination with simazine, Lamont and Spohr (1988) proposed that proteoid roots in Grevillea may be more efficient in absorbing simazine than oxadiazon. Simazine is readily translocated from roots to plant shoots, where it inhibits photosynthesis (Black, 1985; de Prado et al., 1990), while oxadiazon and other herbicides such as oryzalin, oxyfluorfen, and dichlobenil translocate to a limited extent and are known to increase cell membrane permeability at absorption sites (Balke, 1985). The proteoid root system of northern silky oak (which was observed to be present on the test plants) may be particularly efficient at absorbing a range of herbicides, and/or this species may be particularly sensitive to the herbicides tested. Both factors could have contributed to the overall severity of symptoms observed in this species.

Oxyfluorfen + oryzalin, oxadiazon, and oxadiazon + simazine provided excellent weed control at half the recommended rates (applied at $1.1+0.5,2.0$, and $2.0+0.5 \mathrm{~kg} \cdot \mathrm{ha}^{-1}$, respectively), with no plant injury or retardation of plant growth, during 10 weeks on all of the rain forest species tested, except northern silky oak. Further research is required to determine the mechanism of herbicide sensitivity in the Proteaceae to find safe herbicide practices for northern silky oak and other family members.

\section{Literature Cited}

Ahrens, J.F. 1966. Trials with dichlobenil and diphenamid for controlling weeds in containergrown nursery stock. Proc. Northeastern Weed Sci. Soc. 20:232-236.

Balke, N.E. 1985. Herbicide effects on membrane functions, p. 113-140. In: S.O. Duke (ed.). Weed physiology. vol. 2. CRC, Boca Raton, Fla.

Besemer, S.T. and C.L. Elmore. 1987. Weedcontrol in Protea neriifolia 'Pink Mink'. Intl. Protea Assn. J. 12:17-18.

Black, C.C., Jr. 1985. Effects of herbicides on photosynthesis, p. 1-36. In: S.O. Duke (ed.). Weed physiology. vol. 2. CRC, Boca Raton, Fla.

Creager, R.A. 1982. A comparison of oxyfluorfen and oryzalin on container-grown woody ornamentals. HortScience 17:207-209.

Currey, W.L., D.P.H. Tucker, and T.W. Oswalt. 1977. Evaluation of herbicides for containergrown citrus. HortScience 12:66-67.

de Prado, R., R. Scalla, and P. Gaillardon. 1990. Differential toxicity of simazine and diuron to Torilis arvensis and Lolium regidum. Weed Res. 30:213-221.
Donselman, H. and T.K. Broschat. 1986. Phytotoxicity of several pre- and postemergent herbicides on container-grown palms. Proc. Fla. State Hort. Soc. 99:273-274.

Jeffrey, D.W. 1967. Phosphate nutrition of Australian heath plants. 1. The importance of proteoid roots in Banksia (Proteaceae). Austral. J. Bot. 15:403-411

Jones, D.L. 1986. Ornamental rainforest plants in Australia. Reed Books, Frenchs Forest, New South Wales, Australia.

Lamont, G. 1984. The evaluation of five pre-emergent herbicides for weed control in nursery containers. Austral. Hort. 82:27-31.

Lamont, G.P., M.A. O'Connell, and P.J. Nichols. 1985. An evaluation of pre-emergent herbicides for container-grown ornamental plants. Scientia Hort. 26:241-251.

Lamont, G.P. and L.J. Spohr. 1988. Evaluation of oxadiazon and simazine for weed control and phytotoxicity in container-grown ornamental plants. Scientia Hort. 34:93-99.

Neel, P.L. 1977. Effects of oxadiazon preemergence herbicide on weed control and growth of sixteen species of containerized ornamental plants. Proc. Fla. State Hort. Soc. 90:353-355.

Nichols, D.G. and D.V. Beardsell. 1981. The response of phosphorus-sensitive plants to slowrelease fertilisers in soil-less potting mixtures. Scientia Hort. 15:301-309.

Nishimoto, R. 1975. Weed control in established Proteaceae with soil residual herbicides. Proc. 4th Protea Wkshp., Kula, Hawaii, 4-12 Dec. 1974, Univ. of Hawaii Coop. Ext. Serv. Misc. Publ. 139

Singh, M., NC. Glaze, and S.C. Phatak. 1981. Herbicidal response of container-grown Rhododendron species. HortScience 16:213215.

Singh, M., S.C. Phatak, and NC. Glaze. 1984. Response of two container-grown Ilex species to preemergence herbicides. HortScience 19: 117119

Smith, A.J. and J.H. Jooste. 1986. Phosphate absorption by excised ordinary and proteoid roots of Protea compacta R. Br. S. Afr. J. Bot. 52:549551.

Vorster, P.W. and J.H. Jooste. 1986. Potassium and phosphate absorption by excised ordinary and proteoid roots of the Proteaceae. S. Afr. J. Bot. 52:277-281.

Weller, SC., J.B. Masiunas, and P.L. Carpenter. 1984. Evaluation of oxyfluorfen formulations in container nursery crops. HortScience 19:222224.

Table 4. Phytotoxicity rating ${ }^{z}$ on four rain forest species from four granular herbicides evaluated 5 weeks after two 1990 application dates. ${ }^{y, x}$

\begin{tabular}{|c|c|c|c|c|c|c|c|c|c|}
\hline \multirow[b]{2}{*}{ Treatment } & \multirow{2}{*}{$\begin{array}{l}\text { Amount } \\
\text { applied } \\
\left(\mathrm{kg}^{2} \mathrm{ha}^{-1}\right)\end{array}$} & \multicolumn{2}{|c|}{$\begin{array}{l}\text { Corduroy } \\
\text { tamarind }\end{array}$} & \multicolumn{2}{|c|}{$\begin{array}{l}\text { Northern } \\
\text { silky oak }\end{array}$} & \multicolumn{2}{|c|}{ Cluster fig } & \multicolumn{2}{|c|}{ Celerywood } \\
\hline & & Sept. & Dec. & Sept. & Dec. & Sept. & Dec. & Sept. & Dec. \\
\hline \multirow[t]{3}{*}{ Oxadiazon } & 2.0 & $3.3 \mathrm{~b}$ & $1.0 \mathrm{a}$ & $3.3 \mathrm{~b}$ & $4.7 b$ & $1.7 \mathrm{ab}$ & $1.0 \mathrm{a}$ & $3.0 \mathrm{~b}$ & $1.7 \mathrm{ab}$ \\
\hline & 4.0 & $2.7 \mathrm{ab}$ & $1.0 \mathrm{a}$ & $3.3 \mathrm{~b}$ & $4.3 \mathrm{~b}$ & $2.7 \mathrm{~b}$ & $1.0 \mathrm{a}$ & $3.0 \mathrm{~b}$ & $1.7 \mathrm{ab}$ \\
\hline & 8.0 & $3.3 \mathrm{~b}$ & $2.3 \mathrm{a}$ & $3.3 \mathrm{~b}$ & $5.0 \mathrm{~b}$ & $1.7 \mathrm{ab}$ & $1.0 \mathrm{a}$ & $2.0 \mathrm{ab}$ & $2.0 \mathrm{a}-\mathrm{c}$ \\
\hline \multirow[t]{3}{*}{ Oxadiazon + simazine } & $2.0+0.5$ & $2.0 \mathrm{ab}$ & $2.7 \mathrm{a}$ & $3.0 \mathrm{~b}$ & $4.7 \mathrm{~b}$ & $1.3 \mathrm{ab}$ & $1.0 \mathrm{a}$ & $1.7 \mathrm{ab}$ & $1.0 \mathrm{a}$ \\
\hline & $4.0+1.0$ & $3.3 \mathrm{~b}$ & $1.7 \mathrm{a}$ & $2.7 \mathrm{ab}$ & $4.7 b$ & $2.7 \mathrm{~b}$ & $1.0 \mathrm{a}$ & $2.7 \mathrm{ab}$ & $1.0 \mathrm{a}$ \\
\hline & $8.0+2.0$ & $3.0 \mathrm{~b}$ & $1.7 \mathrm{a}$ & $3.7 \mathrm{~b}$ & $5.0 \mathrm{a}$ & $1.0 \mathrm{a}$ & $1.0 \mathrm{a}$ & $3.7 \mathrm{~b}$ & $3.0 \mathrm{c}$ \\
\hline \multirow[t]{3}{*}{ Oxadiazon + oryzalin } & $1.1+0.5$ & $3.7 \mathrm{~b}$ & $1.0 \mathrm{a}$ & $3.3 \mathrm{~b}$ & $5.0 \mathrm{~b}$ & $1.0 \mathrm{a}$ & $1.0 \mathrm{a}$ & $1.0 \mathrm{a}$ & $1.0 \mathrm{a}$ \\
\hline & $2.2+1.0$ & $3.7 \mathrm{~b}$ & $2.0 \mathrm{a}$ & $2.3 \mathrm{ab}$ & $4.7 \mathrm{~b}$ & $1.0 \mathrm{a}$ & $1.0 \mathrm{a}$ & $3.0 \mathrm{~b}$ & $2.3 \mathrm{bc}$ \\
\hline & $4.4+2.0$ & $2.3 \mathrm{ab}$ & $1.0 \mathrm{a}$ & $3.0 \mathrm{~b}$ & $4.7 b$ & $1.0 \mathrm{a}$ & $1.0 \mathrm{a}$ & $2.0 \mathrm{ab}$ & $1.0 \mathrm{a}$ \\
\hline \multirow[t]{3}{*}{ Dichlobenil } & 1.0 & $2.3 \mathrm{ab}$ & $1.7 \mathrm{a}$ & $3.3 \mathrm{~b}$ & $5.0 \mathrm{~b}$ & $1.0 \mathrm{a}$ & $1.0 \mathrm{a}$ & $1.0 \mathrm{a}$ & $1.0 \mathrm{a}$ \\
\hline & 2.0 & $3.0 \mathrm{~b}$ & $1.7 \mathrm{a}$ & $3.0 \mathrm{~b}$ & $5.0 \mathrm{~b}$ & $1.7 \mathrm{ab}$ & $1.0 \mathrm{a}$ & $3.3 \mathrm{~b}$ & $1.7 \mathrm{ab}$ \\
\hline & 4.0 & $3.7 \mathrm{~b}$ & $1.0 \mathrm{a}$ & $3.7 \mathrm{a}$ & $4.7 \mathrm{~b}$ & $1.0 \mathrm{a}$ & $1.0 \mathrm{a}$ & $2.7 \mathrm{ab}$ & $1.7 a b$ \\
\hline Nontreated control & & $1.0 \mathrm{a}$ & $1.0 \mathrm{a}$ & $1.0 \mathrm{a}$ & $1.0 \mathrm{a}$ & $1.0 \mathrm{a}$ & $1.0 \mathrm{a}$ & $1.0 \mathrm{a}$ & $1.0 \mathrm{a}$ \\
\hline
\end{tabular}

${ }^{2}$ Phytotoxicity rating: 1 = no plant injury (control), $2=$ minor injury, $3=$ moderate injury, $4=$ severe injury, and $5=$ plant death due to herbicide.

YMean separation within columns by LSD at $P \leq 0.05$.

${ }^{x}$ Species not mentioned rated 1.0 (no plant injury) for all herbicides and both evaluation dates. 